\title{
Impact of risk on the saving pattern in present scenario: ways and means to diversify it
}

\author{
Dr. M.K Rastogi ${ }^{1}$, Ms. Meenakshi Chaturvedi ${ }^{2}$ \\ ${ }^{1}$ Professor \& Head, BBDNIIT, Faizabad Road, Lucknow, Uttar Pradesh - 227015 India \\ ${ }^{2}$ Research scholar, School of Management,BBD University, Faizabad Road, Lucknow, Uttar Pradesh-227015 \\ India.
}

\begin{abstract}
Risk and its consequences cause a terrible threat to saving pattern in present scenario. The saving rate will probably continue to rise but if we notice that the saving rate shows fluctuation and went negative during the depression as investor used savings to supplement income. This study examines the impact of risk on saving pattern and different ways to diversify it.

This paper aims to study different types of risk which affect the saving pattern and various strategies used by investor to diversify their risk. After analyzing the data related to Gross Domestic Saving and Gross Capital Formation from the Economic Survey of India a positive correlation comes between Gross Domestic Saving and Gross Capital formation. Study also shows that risk causes an inverse impact on the saving of the investor because every investor wants to make a balance between their risk and return.
\end{abstract}

\section{Introduction}

If an Investor had invested Rs. 1,000 in a portfolio of large-company stocks in 2001 and then reinvested all dividends received, his or her investment must have grown to Rs. 2,845,697 by 2010 . Over the same time period, a portfolio of small-company stocks would have grown even more, to Rs. 6,641,505. But, if he or she had invested in long-term government bonds, the Rs. 1,000 would have grown to only Rs.40, 219 and to a measly Rs. 15,642 for short-term bonds. Given these numbers, why anyone should invest in bonds? The answer is, "Because bonds are less risky." While common stocks have over the past 74 years produced considerably higher returns.(1) One cannot predict that the past is a prologue to the future, (2) The stock values are more likely to experience sharp declines than bonds, so one has a greater chance of losing money on a stock investment.

Hence, risk can be defined as the fluctuation in expected return or the probability that an actual return on an investment will be lower than the expected return.

Risk can be divided into two components i.e. exposure and uncertainty. In a financial institution, a financial risk is the probability that an action or event's outcome could have adverse impacts. These outcomes lead to loss of capital or earnings or could result in constraints being imposed on the financial institution's ability of satisfy the business objectives. These constraints could impose risks such as hindering the ability of a bank to benefit from opportunities in order to improve its business or to carry out the ongoing business.

\subsection{OBJECTIVE OF RESEARCH}

- To identify various types of risk.

- To identify saving pattern of the household

- To analyze the impact of risk on saving pattern

- To identify the various tools to diversify the risk

\subsection{CLASSIFICATION OF RISKS}

Risks are defined based on the negative impact they have on the profits from the various sources. Almost all the banks or financial institutions need to face and manage the following risks Generally speaking, according to Guidelines for Risk Management there exist four types of risks which affect the 


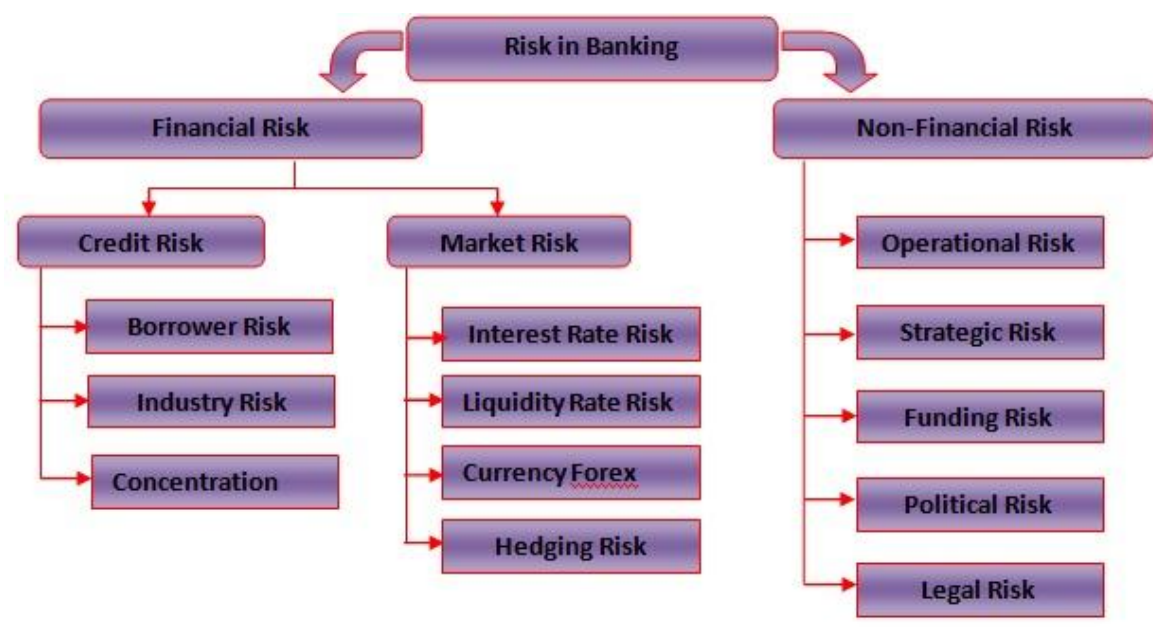

Fig. 1 Types of Risks

financial industry namely Operational Risk, Liquidity Risk, Market Risk and Credit Risk. Following in the explanation of these risks:

\subsubsection{CREDIT RISK}

A credit risk is incurred due to counter-party defaults. This type of risk occurs due to investing, lending activities and due to the buying or selling of financial assets for others. This type of risk is related to financial transactions, that is:

- Default by a borrower in making a repayment, and

- Default in fulfilling the agreement by another bank or financial institution with respect to syndicated arrangements.

Credit risks are very critical in the banking sector and need to be managed with upmost care. Credit risks require highest level of subjective judgement in spite of constant efforts for quantifying and improving credit decision processes.

\subsubsection{MARKET RISK}

The term market risk defines the unpredictability of market value or income because of the fluctuations that occur in underlying market issues such as credit spreads, currency, and interest rates. For commercial financial institutions, market risk arises due to mismatches that occur between an asset's risk profile and its funding. Marker risk includes interest rate risks in all its components: commodity risk, exchange risk and equity risk.

\subsubsection{LIQUIDITY RISK}

The term liquidity risk defines the risk of being unable to meet commitments or being unable to offset or wind positions by a company within the time constraints. This is because it will lead to non-liquidation of assets at rational costs when required.

\subsubsection{NON-FINANCIAL RISK}

Non-financial risk refers to those risks that may affect a bank's business growth, marketability of its product and services, likely failure of its strategies aimed at business growth etc. These risks may arise on account of management failures, competition, non-availability of suitable products/services, external factors etc. In these risk operational and strategic risk have a great need of consideration.

\subsubsection{OPERATIONAL RISK}

An operational risk occurs due to insufficiency in the organisation, conception and implementation of processes for recording event with respect to the operation of a bank in the information system or accounting system.

\section{Saving Pattern Of Household}

In the present scenario of investment market, the saving and investment pattern of the household is changing. To analyze the effect of risk saving on the saving pattern, the savings pattern of the sample investor is studied. The information showing the saving pattern of the sample investor is furnished in TABLE 1. 
Table 1 Saving Pattern of sample investor

\begin{tabular}{|l|l|l|}
\hline \multicolumn{3}{|c|}{ Percentage Of Saving } \\
\hline $\begin{array}{l}\text { Saving as \% of } \\
\text { Annual Income }\end{array}$ & $\begin{array}{l}\text { No.of } \\
\text { Respedent }\end{array}$ & \% of Total \\
\hline $\mathbf{0 1 - 1 0 \%}$ & $\mathbf{1 3 8}$ & $\mathbf{2 6 . 2}$ \\
\hline $\mathbf{1 1 - 2 0 \%}$ & $\mathbf{2 0 0}$ & $\mathbf{3 8 . 0}$ \\
\hline $\mathbf{2 1 - 3 0 \%}$ & $\mathbf{1 2 1}$ & $\mathbf{2 3 . 0}$ \\
\hline Over 30\% & $\mathbf{4 5}$ & $\mathbf{8 . 6}$ \\
\hline No Saving & $\mathbf{2 2}$ & $\mathbf{4 . 2}$ \\
\hline Total & $\mathbf{5 2 6}$ & $\mathbf{1 0 0}$ \\
\hline
\end{tabular}

Source - Data Source Population Survey

\section{Saving Pattern Of The Sample Investor}

It may be noted from the information given in the TABLE 1 that the most of the respondent are able to save between $10-30 \%$ of the annual income. Only a few of the respondent, i.e. around $4 \%$ of the total respondent were not able to save from their income. It can be noted that $38 \%$ of the total respondent are able to save to the extent of $10-20 \%$ of their annual income. While $23 \%$ are saving between $21-30 \%$. And $9 \%$ are saving over the $30 \%$ of their annual income. It is therefore, concluded that most of the sample investors are able to save substantially out of their annual income and is in position to make investment.

Table 2 Gross Domestic saving and Gross Fixed Capital Formation

\begin{tabular}{|c|c|c|c|c|c|c|}
\hline & \multicolumn{3}{|c|}{ Gross Domestic Saving } & \multicolumn{3}{|c|}{ Gross Fixed Capital Formation } \\
\hline Year & $\begin{array}{l}\text { Private } \\
\text { Corporate } \\
\text { Sector }\end{array}$ & $\begin{array}{l}\text { Public } \\
\text { Sector }\end{array}$ & $\begin{array}{l}\text { Total } \\
(2+3)\end{array}$ & $\begin{array}{l}\text { Public } \\
\text { Sector }\end{array}$ & $\begin{array}{l}\text { Private } \\
\text { Sector }\end{array}$ & $\begin{array}{l}\text { Total } \\
(5+6)\end{array}$ \\
\hline 1 & 2 & 3 & 4 & 5 & 6 & 7 \\
\hline $2000-01$ & 3.9 & -1.8 & 2.1 & 6.5 & 16.3 & 22.8 \\
\hline 2001-02 & 3.4 & -2.0 & 1.4 & 6.5 & 17.1 & 23.6 \\
\hline $2002-03$ & 4.0 & -0.6 & 3.4 & 6.3 & 17.6 & 23.9 \\
\hline 2003-04 & 4.6 & 1.1 & 5.7 & 6.5 & 18.5 & 25.0 \\
\hline 2004-05 & 6.6 & 2.3 & 8.9 & 6.9 & 21.8 & 28.7 \\
\hline 2005-06 & 7.5 & 2.4 & 9.9 & 7.3 & 23.0 & 30.3 \\
\hline 2006-07 & 7.9 & 3.6 & 11.5 & 7.9 & 23.4 & 31.3 \\
\hline 2007-08 & 9.4 & 5.0 & 14.4 & 8.0 & 24.9 & 32.9 \\
\hline 2008-09 & 7.9 & 0.5 & 8.4 & 8.6 & 23.5 & 32.1 \\
\hline 2009-10 & 8.1 & 2.1 & 10.2 & 8.4 & 22.3 & 30.7 \\
\hline
\end{tabular}

Source - Economic Survey of India 2010-11, Statistical Appendix

These data reveal that Gross domestic saving in private sector is more than public sector with an increasing trend from 2001-02 to 2007-08 except year 2008-09 where it has shows a (-ve) negative trend. The same trends can be visualized in the Gross fixed capital formation.

Hence, it can be seen that investors prefer to invest in private sector instruments than public sector instruments even though private sector securities are highly volatile and subjected to high risk than public sector securities.

Another fact is higher the risk higher the return which can be seen in the TABLE 1 that $38 \%$ investor invested $11-20 \%$ of their income.

$>$ Income generation

\section{Reason For Investment In Private Sector}

$>$ High return

$>$ Education wise income distribution

$>$ No. of young investor is high

$>$ High risk taking ability of investor

$>$ Increase in disposable income 
Table 3 Investment Objective(Percentage basis)

\begin{tabular}{|l|l|l|l|l|l|l|l|}
\hline Preference & Safety & $\begin{array}{l}\text { Liquidity\& } \\
\text { marketability }\end{array}$ & $\begin{array}{l}\text { income } \\
\text { generation }\end{array}$ & $\begin{array}{l}\text { Capital } \\
\text { appreciation }\end{array}$ & $\begin{array}{l}\text { Tax } \\
\text { benefit }\end{array}$ & Diversification & Total \\
\hline $1^{\text {st }}$ & 62.4 & 4.2 & 23.2 & 5.1 & 6.3 & 3.0 & 104.20 \\
\hline $2^{\text {nd }}$ & 21.9 & 14.8 & 49.0 & 8.0 & 9.1 & 4.4 & 107.20 \\
\hline $3^{\text {rd }}$ & 7.4 & 26.2 & 13.7 & 13.1 & 34.2 & 4.4 & 99.00 \\
\hline $4^{\text {th }}$ & 3.6 & 28.3 & 8.2 & 25.9 & 18.3 & 12.6 & 96.90 \\
\hline $5^{\text {th }}$ & 4.2 & 18.4 & 4.6 & 27.8 & 20.5 & 23.7 & 99.20 \\
\hline $6^{\text {th }}$ & 0.5 & 8.1 & 1.3 & 20.1 & 11.6 & 51.9 & 93.50 \\
\hline Total & 100 & 100 & 100 & 100 & 100 & 100 & 600 \\
\hline
\end{tabular}

Source - Data Source Population Survey

Information presented in TABLE 2 reveals that most of the sample investors, i.e. $62.4 \%$ of them, has indicated that 'safety of the investment' as their first objective in choosing the investment alternative. The second objective influencing the investor behavior and preferences in the selection of investment alternative is 'income' earned from the investment made. This is stated by $49 \%$ of the total. The two objectives are followed by liquidity and marketability, capital appreciation, tax benefit and diversification benefits.

Table 4 Education-wise distribution of Investment Avenues with high Awareness

\begin{tabular}{|l|l|l|l|l|l|}
\hline $\begin{array}{l}\text { Educational } \\
\text { Qualification }\end{array}$ & Bank Deposits & Real-estate & $\begin{array}{l}\text { Small saving } \\
\text { scheme }\end{array}$ & LIC & Bullion \\
\hline Post Graduation & 82.9 & 76.6 & 83.8 & 86.5 & 74.8 \\
\hline Graduation & 85.2 & 83.3 & 81.0 & 82.9 & 77.1 \\
\hline Intermediate & 76.1 & 76.6 & 66.5 & 64.4 & 57.4 \\
\hline No. & 29.4 & 64.7 & 41.2 & 41.2 & 82.4 \\
\hline \multicolumn{6}{|l}{ Source - Data Source Population Survey }
\end{tabular}

It is clear in the TABLE 4 that there is no difference significant in respect of graduates and post graduates. However, there is a decline in percentage in respect of respondents whose educational level is intermediate or below. Further a significant decline has seen in respondent with no further formal education. It is therefore, evident that education is an important factor in influencing the level of awareness in the investor about various investment avenues available to them.

Table 5 Education-wise distribution of Investment Avenues with Low Awareness

\begin{tabular}{|l|l|l|l|l|l|}
\hline Educational Qualification & $\begin{array}{l}\text { Corporate } \\
\text { Deposits }\end{array}$ & $\begin{array}{l}\text { Corporate } \\
\text { Bonds }\end{array}$ & $\begin{array}{l}\text { Mutual } \\
\text { Funds }\end{array}$ & $\begin{array}{l}\text { Equity } \\
\text { Shares }\end{array}$ & $\begin{array}{l}\text { Preference } \\
\text { Shares }\end{array}$ \\
\hline Post Graduation & 54.1 & 35.0 & 39.6 & 44.1 & 37.8 \\
\hline Graduation & 45.2 & 33.8 & 29.0 & 35.7 & 37.6 \\
\hline Intermediate & 16.5 & 8.0 & 21.8 & 8.0 & 6.4 \\
\hline No. & 11.8 & 0.0 & 5.9 & 0.0 & 23.5 \\
\hline
\end{tabular}

Source - Data Source Population Survey

\subsection{AGE AND INVESTOR AWARENESS}

The relation between age and awareness of investors, the age-wise distribution of investment avenues with high awareness and also with low awareness amongst the investors is analyzed hereunder.

Table 6 Age-wise distribution of Investment Avenues with High Awareness

\begin{tabular}{|l|l|l|l|l|l|}
\hline \multirow{2}{*}{$\begin{array}{l}\text { Age in Year } \\
\text { Below 30 }\end{array}$} & Bank In Deposits & Real Estate & SSS & LIC & Bullion \\
\cline { 2 - 6 } & 74.6 & 92.1 & 65.1 & 63.5 & 77.8 \\
\cline { 2 - 6 } $41-50$ & 78.4 & 83.0 & 72.1 & 70.5 & 69.3 \\
\cline { 2 - 6 } 51-60 & 82.8 & 74.5 & 85.5 & 83.5 & 65.5 \\
\cline { 2 - 7 } Above 60 & 78.8 & 76.0 & 68.5 & 69.9 & 69.9 \\
\cline { 2 - 7 } & 81.0 & 77.4 & 78.5 & 86.9 & 71.4 \\
\hline
\end{tabular}

Source - Data Source Population Survey 
It may be seen from TABLE 6 that the respondents are almost equally distributed among the different age group while claiming their high level of awareness about these avenues. Therefore, the age of investor cannot be taken to influence their level of awareness.

Table 7 Age-wise distribution of Investment Avenues with Low Awareness

\begin{tabular}{|l|l|l|l|l|}
\hline Corporate deposits & Corporate Bond & Mutual Fund & Equity Share & Preference \\
\hline 44.4 & 31.7 & 38.1 & 39.7 & 31.7 \\
\hline 42.0 & 39.8 & 31.8 & 25.0 & 34.1 \\
\hline 39.3 & 29.0 & 29.0 & 28.3 & 26.2 \\
\hline 26.7 & 28.1 & 17.8 & 19.2 & 17.1 \\
\hline 32.1 & 22.6 & 32.1 & 27.4 & 28.6 \\
\hline
\end{tabular}

Source - Data Source Population Survey

Table 8 Changes in Stock and Gross Capital Formation

\begin{tabular}{|c|c|c|c|c|c|c|c|c|c|}
\hline \multicolumn{3}{|c|}{ Cange in Stock } & \multicolumn{7}{|c|}{ Gross Fixed Capital Formation } \\
\hline & $\begin{array}{l}\text { Private } \\
\text { Sector }\end{array}$ & $\begin{array}{l}\text { Total } \\
(8+9)\end{array}$ & $\begin{array}{l}\text { Public } \\
\text { Sector }\end{array}$ & $\begin{array}{l}\text { Private } \\
\text { Sector }\end{array}$ & Valuables & $\begin{array}{l}\text { Total } \\
(11+12)\end{array}$ & $\begin{array}{l}\text { Errors \& } \\
\text { Omissions }\end{array}$ & $\begin{array}{l}\text { Adjusted } \\
\text { Year }(14+15)\end{array}$ & Correlation \\
\hline 8 & 9 & 10 & 11 & 12 & 13 & 14 & 15 & 16 & 17 \\
\hline 0.4 & 0.3 & 0.7 & 6.9 & 16.6 & 0.7 & 24.2 & 0.2 & 24.4 & \multirow{3}{*}{ ભू } \\
\hline 0.4 & -0.4 & 0.0 & 6.9 & 16.7 & 0.6 & 24.2 & -1.3 & 22.9 & \\
\hline-0.2 & 1.0 & 0.8 & 6.1 & 18.6 & 0.6 & 25.3 & 0 & 25.3 & \\
\hline-0.1 & 1.0 & 0.9 & 6.3 & 19.6 & 0.9 & 26.8 & 0.8 & 27.6 & \multirow{7}{*}{ 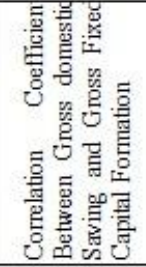 } \\
\hline 0.5 & 2.0 & 2.5 & 7.4 & 23.8 & 1.3 & 32.5 & 0.4 & 32.9 & \\
\hline 0.6 & 2.2 & 2.8 & 7.9 & 25.2 & 1.1 & 34.2 & 0.4 & 34.6 & \\
\hline 0.4 & 3.0 & 3.4 & 8.3 & 26.4 & 1.2 & 35.9 & -0.2 & 35.7 & \\
\hline 0.8 & 3.2 & 4.0 & 8.9 & 28.1 & 1.1 & 38.1 & 0.1 & 38.2 & \\
\hline 0.9 & 1.1 & 2.0 & 9.5 & 24.6 & 1.3 & 35.4 & -0.8 & 34.6 & \\
\hline 0.8 & 2.5 & 3.3 & 9.2 & 24.9 & 1.7 & 35.8 & 0.7 & 36.5 & \\
\hline
\end{tabular}

As we can see from TABLE no. 8 that there is more gross fixed capital formation from private sector than public sector and the correlation comes between both the factor is 0.93959 which is very high and approx 1 which shows that both the factors i.e. risk and return are unitary correlated to each other.

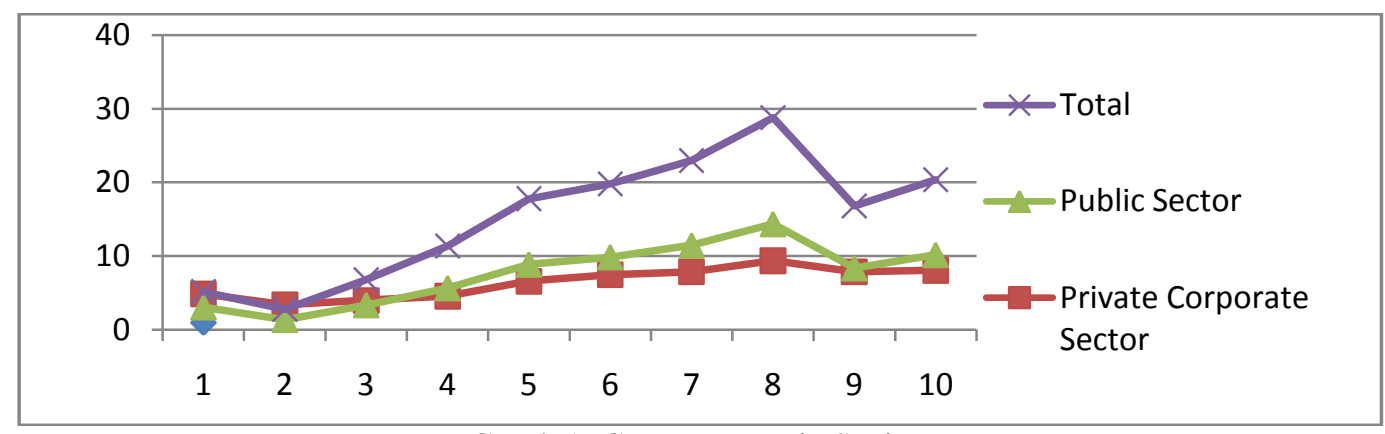

Graph 1: Gross Domestic Saving

As we can see in the Graph 1 that initially investor invested more in private sector and then it shifted to public sector.

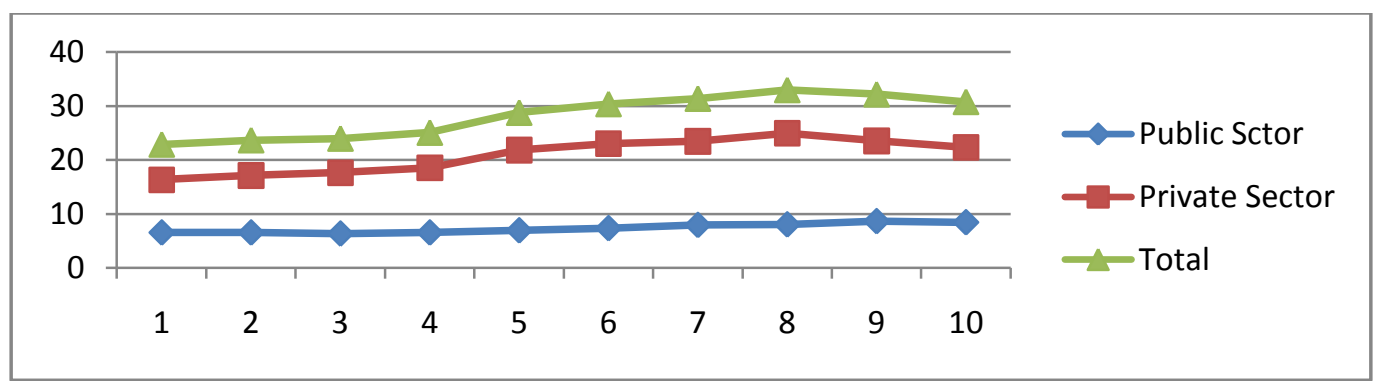

Graph 2: Gross Fixed Capital Formation 
It is clearly represented in graph 2 that more fixed capital is generated from private sector than public sector

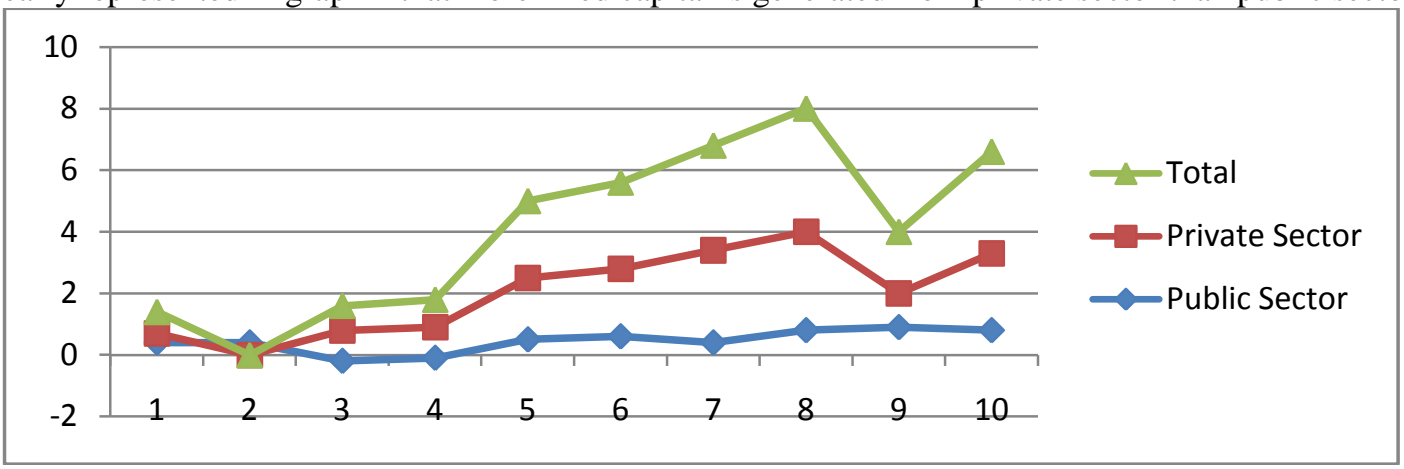

Graph 3: Change in Stock

There is more change in stock in private sector than public sector.

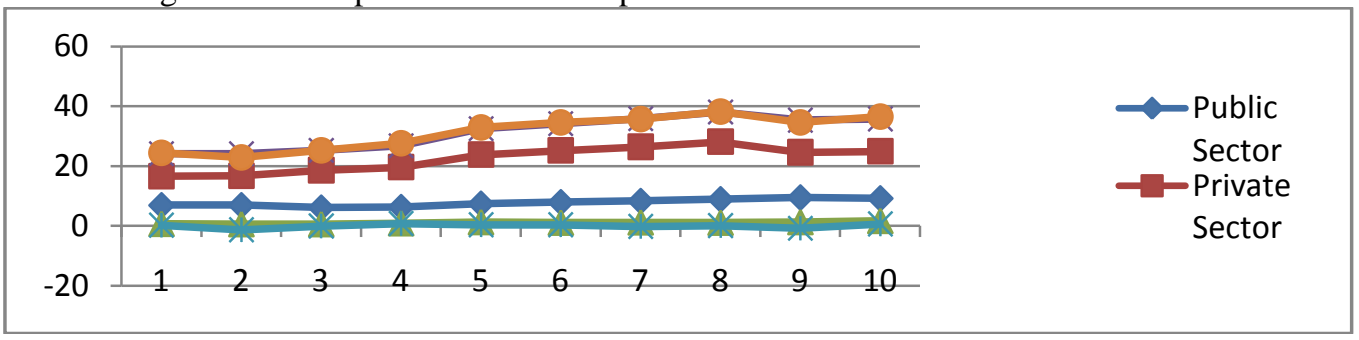

Graph 4:Gross Fixed Capital Formation

Private sector contributed much in gross fixed capital formation than public sector

\subsection{TYPES OF RISK MANAGEMENT BY INVESTOR:}

$>$ Ex-ante strategies: Before the risk occurs, trying to prevent risk affecting the household or to mitigate the impact of risk

$>$ Ex-post strategies: After the risky event occurs, reducing its impact (coping) (while ex-ante preparing for this)

Risk strategies used by Investor to reduce ex-post:

$>$ Informal credit

$>$ Savings (grain storage, livestock)

$>$ Informal Insurance Arrangements (mutual support; insurance groups)

$>$ Family Labour adjustments (including child labour)

Risk strategies used by Investor to mitigate ex-ante:

$>$ Diversification,

$>$ Low risk activities

$>$ Marriage/migration patterns

\section{CONCLUSION}

Managing risk is one of the top topics for discussion in the financial industry. The notion of risk has a growing significance in the modern financial industry. The operating environment in today's business requires highly integrated and systematic approach for risk management. As we already discussed in the paper that risk and return is approximately unitary correlated .And there are various factors responsible for it .And various expost and ex-ante techniques to manage and diversify risk which are discussed in this paper.

\section{References}

[1] Volume: 21, Issue: 3, Publisher: Cambridge, Mass.: Massachusetts Institute of Technology, Pages: 17-31 ISSN: 0019848X DOI: $10.1002 / \mathrm{smj} .734$.

[2] "Study of Saving Pattern and Investment Preferences of Individual Household in India" At International Journal Of Research In Commerce \& Management VOLUME NO. 3 (2012), Issue No. 5 (May) ISSN 0976-2183.

[3] V.A. Avdhani, Investment and Securities Markets in India-, Himalaya Publications, New Delhi.

[4] Sloan Management Review (1980).

[5] Economic Survey 2010-11, Website: http://indiabudget.nic.in/1.5: GROSS DOMESTIC SAVING AND GROSS FIXED CAPITAL FORMATION (At current prices).

[6] http://www.offshoremerchants.net/high-risk-merchant-accounts-risk-and-its-types-in-risk-management-in-the-financial-sector.htm.

[7] https://en-us. Add-ons.mozilla.com/en-US/firefox/bookmarks.

[8] http://onlinelibrary.wiley.com/doi/10.1111/j.1468-0351.1996.tb00176.x/abstract. 